\title{
Hydrochemical Characteristics and Controlling Factors of Typical Dolomite Karst Basin in Humid Subtropical Zone
}

\author{
Shizhen Xiao $\mathbb{D}^{1},{ }^{1}$ Cheng Zeng $\mathbb{D},{ }^{1,2}$ Jiacheng Lan $\mathbb{D}^{1},{ }^{1}$ Yongning Di, ${ }^{1}$ Jianghu He, ${ }^{1}$ Hua Xiao, ${ }^{1}$ \\ and Jialu Wang $\mathbb{1}^{3}$ \\ ${ }^{1}$ School of Karst Science, Guizhou Normal University/State Engineering Technology Institute for Karst Desertification Control, \\ Guiyang 550002, China \\ ${ }^{2}$ State Key Laboratory of Environmental Geochemistry, Institute of Geochemistry, Chinese Academy of Sciences, \\ 550081 Guiyang, China \\ ${ }^{3}$ School of Resource and Environmental Engineering, Anshun University, Anshun, 561000 Guizhou, China
}

Correspondence should be addressed to Cheng Zeng; zcchampion@qq.com, Jiacheng Lan; lanjc2016@163.com, and Jialu Wang; wangil226@126.com

Received 19 July 2020; Revised 5 March 2021; Accepted 26 March 2021; Published 15 April 2021

Academic Editor: Carmine Apollaro

Copyright (C) 2021 Shizhen Xiao et al. This is an open access article distributed under the Creative Commons Attribution License, which permits unrestricted use, distribution, and reproduction in any medium, provided the original work is properly cited.

\begin{abstract}
The hydrochemical characteristics and variation rules of water in karst areas are important for the basic research of karst field. Because only a few researches focused on the hydrochemical characteristics of humid subtropical dolomite karst basins in the past, the Shanmuhe Basin and its subbasin Huangzhouhe Basin in Shibing Dolomite Karst World Natural Heritage Site in China were selected as the study area. A total of 215 water samples were collected and analyzed. It was found that the hydrochemical type of subtropical dolomite karst basin is $\mathrm{HCO}_{3}-\mathrm{Ca} \cdot \mathrm{Mg}$ type, which is different from that in limestone areas and shale districts, which is $\mathrm{HCO}_{3}-\mathrm{Ca}$ type for both; $\mathrm{EC}, \mathrm{Ca}^{2+}, \mathrm{Mg}^{2+}, \mathrm{HCO}_{3}^{-}, \mathrm{Mg}^{2+} / \mathrm{Ca}^{2+}$, and $\mathrm{Mg}^{2+} / \mathrm{HCO}_{3}^{-}$have similar spatial variations, which are lower in allogenic water in the upstream in the northwest of the basin and become higher when the water enters the dolomite karst area in the mid and downstream of the basin, and $\mathrm{SI}_{\mathrm{C}}$ and $\mathrm{SI}_{\mathrm{D}}$ of the allogenic water in the upstream are below zero, while those become saturated after entering the dolomite area in the mid and downstream; the monthly variation of hydrochemistry shows that the seasonal variation of ion concentration is not obvious, and there is a dilution effect in rainy seasons, but the variation of ion concentration is small and relatively stable; higher $\mathrm{HCO}_{3}{ }^{-}$concentration and $\mathrm{Mg}^{2+} / \mathrm{Ca}^{2+}$ in the pure dolomite basin are higher than those in the impure dolomite basin; the main influencing factors of the hydrochemical features are geological background especially the lithology, and the water chemistry is mainly controlled by rock weathering and water-rock interaction; rainfall import is low and the low concentrations of $\mathrm{K}^{+}, \mathrm{Na}^{+}, \mathrm{NO}_{3}^{-}, \mathrm{Cl}^{-}$, and $\mathrm{SO}_{4}^{2-}$ in water indicate that human activities have little effect on the hydrochemistry in the study area.
\end{abstract}

\section{Introduction}

The influence of water dissolution of carbonate rock will be directly reflected by the hydrochemical characteristics of water. The chemical weathering of rocks and soils occurs under the leaching of rainwater, and leaching ions enter rivers. Therefore, the hydrochemical composition of rivers has become the main way to study the chemical weathering process of rocks recently and has been widely used in the world. By studying the hydrochemical characteristics of rivers, we can get the exogenous circulation process of chemical weath- ering, climate, and average chemical elements of upper crust in the continent-river-ocean system [1]. The hydrochemical types, compositions, temporal and spatial variations, and ion sources of surface rivers have been studied in depth [2-5]. As early as the 1970s, some scholars studied the hydrochemical characteristics of karst basins dominated by limestone and gypsum [6-8]. In China, the geochemistry of surface water and groundwater in karst basins was also studied. In surface river basins, the characteristics and sources of hydrochemistry and isotopes were mainly studied $[1,9]$; and the regional hydrochemical differences between surface water and 
groundwater and their causes were discussed from the regional scale $[10,11]$. From the perspective of the impact of land use and human activities on hydrochemistry, water quality, and stable isotopes of dissolved inorganic carbon in karst groundwater, more extensive and in-depth studies were conducted [12-17]. Based on preliminary identification of karst distribution and hydrogeochemical characteristics of typical karst areas in Thailand, Zhang et al. [18] analyzed the main characteristics and dynamic conditions of karst development in Thailand and compared them with those in southwest China. The main karst strata in Thailand are Ordovician, Permian, and Triassic limestone. However, most of the researches are focusing on limestone karst areas, and studies of dolomite karst area are insufficient. Researches on the hydrochemistry of dolomite karst in tropical-subtropical climatic conditions are more insufficient. Cowell et al. [19] studied the hydrochemistry of dolomite karst area under climate in temperate zone and pointed out that the hydrochemical type in this area is $\mathrm{HCO}_{3}-\mathrm{Ca} \cdot \mathrm{Mg}$ type; calcite saturation index $\left(\mathrm{SI}_{\mathrm{C}}\right)$ and dolomite saturation index $\left(\mathrm{SI}_{\mathrm{D}}\right)$ of surface water are both above 0 , which represents mature landforms. Zhang [20] studied the dolomite in Luocheng, Guangxi, China, and pointed out that the hydrochemical type in this area was $\mathrm{HCO}_{3}-\mathrm{Ca} \cdot \mathrm{Mg}$ type; when dolomite dissolves, calcite leaches preferentially. Dolomite is as commonly distributed as limestone in the world [21]. The dolomite and dolomitelimestone interbedding lithology account for $25.7 \%$ of the total distribution area of carbonate rocks in China. Therefore, more attention should be given on the research on dolomite karst areas.

Under the background of serious large-scale rocky desertification in karst areas of Guizhou, China, Shibing has become a good place for the study of dolomite karst in China and even in the whole world because of the preservation of the natural dolomite karst process in a relatively pure dolomite geological background with primary forest coverage. Yunnan, Guangxi, Hunan, and Hubei also have large areas of dolomite, but most of them are dolomite with limestone interbedded or limestone dolomite, while Shibing retains pure dolomite with a total thickness of $1100 \mathrm{~m}$. Therefore, Shibing, Guizhou, in China was finally selected as the most typical example of the subtropical karst area developed on dolomite in the world and was successfully inscribed on the World Heritage List in 2014 as an irreplaceable component of the South China Karst. Shibing Karst, which has the best known example of subtropical fengcong karst in dolomite, provides a spectacular fengcong landscape, which is also exceptional because it developed in relatively insoluble dolomite rocks (UNESCO World Heritage Committee, 2014). It is one of the ideal and natural places to study dolomite karst. In this paper, the Shanmuhe (Shanmu River) Basin and its subbasin Huangzhouhe (Huangzhou River) Basin in Shibing, Guizhou Province, were selected as the study areas, and the hydrogeochemical characteristics of dolomite rock weathering were revealed through manual survey and intensive monitoring of hydrochemistry in the basin. On the basis of dividing the underground basin of $1: 50000$ and $1: 200000$ hydrogeological maps in the study area, combined with $1: 50000$ and $1: 10000$ topographic maps, through field hydrogeological survey and hydrochemical analysis, Shanmuhe and Huangzhouhe basins were defined. The main springs and surface water from upstream to downstream of Shanmuhe Basin were sampled jointly by hydrochemical method, the differences analyzed, and the controlling factors of weathering and karstification in dolomite basin discussed as a function of lithology, precipitation, and human activities.

\section{Study Area}

The study area, including Shanmuhe Basin and its subbasin Huangzhouhe Basin (Figure 1) in Shibing Dolomite Karst World Natural Heritage Site, is located in Shibing County, Guizhou Province, China, which is the hilly slope zone of the transition from Yunnan-Guizhou plateau to western Hunan hills. The total area of Shanmuhe Basin is $242.00 \mathrm{~km}^{2}$, and the area of dolomite outcrop is $192.34 \mathrm{~km}^{2}$, accounting for $80 \%$ of the total area of the basin and making it a typical dolomite basin. The area of Huangzhouhe Basin, the subbasin of Shanmuhe Basin, is about $49.19 \mathrm{~km}^{2}$, which is not affected by allogenic water. Except for a small amount of Ordovician limestone and argillaceous limestone in the lower part of the Cambrian Qingxudong Formation, the vast majority of the basin $\left(45.27 \mathrm{~km}^{2}, 92 \%\right)$ is Cambrian Shilengshui Formation dolomite, trans-Cambrian-Ordovician Loushanguan Formation dolomite, and a small amount of fine-grained dolomite. It has become an ideal basin for the study of subtropical dolomite karst process nationwide and even globally, with a high degree of typicality and representativeness.

\section{Methodology}

3.1. Water Sample Collection. The purpose is to study the hydrochemical characteristics of subtropical dolomite karst area. According to the geological background and hydrogeological characteristics of the basin and considering the influence of lithology on water, groundwater and surface water were sampled from 39 points (Figure 1 and Table 1) from upstream to downstream of the Shanmuhe Basin from May 2014 to July 2016, including 14 points of groundwater (Nos. 26-39, 1 allogenic groundwater sample, 12 karst groundwater samples) and 25 points of surface water (Nos. 1-25: Nos. 1-22 are karst water samples, and Nos. 22-24 are allogenic water). Two samples of atmospheric precipitation were obtained during the period. Most of these water are sampled monthly or seasonally to understand the basic hydrochemical characteristics, influencing factors, and temporal and spatial variations of the dolomite basin. On the basis of surface water sample collection and analysis, the key point is to select No. 4 outlet of Huangzhouhe Basin for intensive collection and monitoring. A total of 215 water samples were collected.

Sampling method: at the sampling site, water temperature $(T), \mathrm{pH}$, conductivity (EC), and dissolved oxygen (DO) were measured by French PONSEL ODEON portable digital water quality measuring recorder, with the accuracy of $0.1^{\circ} \mathrm{C}$, $0.01 \mathrm{pH}$ unit, $1 \mu \mathrm{S} / \mathrm{cm}$, and $0.01 \mathrm{mg} / \mathrm{L}$, respectively. The calibration methods include the following. (1) The temperature sensor is calibrated annually, in a 2-step process: the sensor 

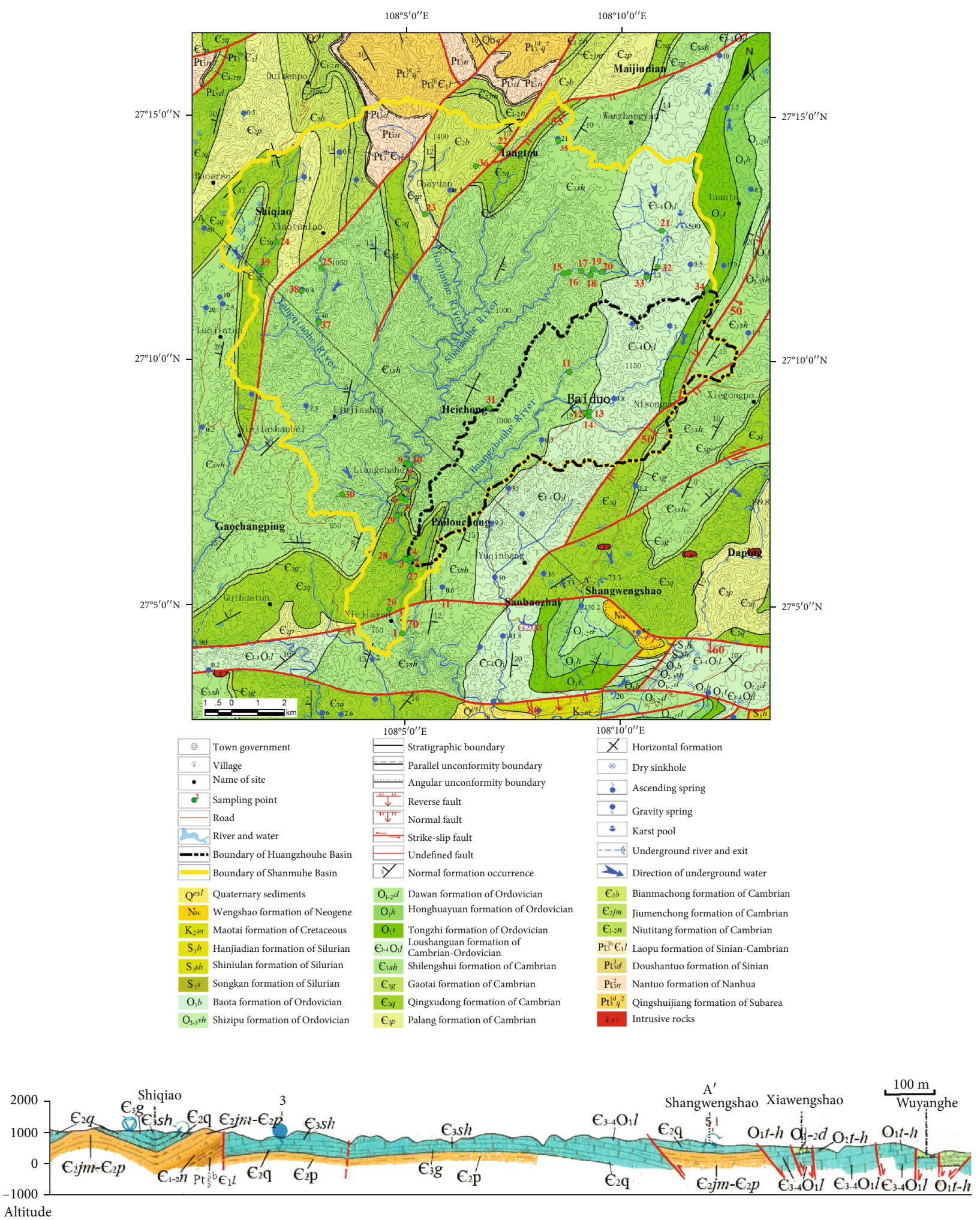

Figure 1: Distribution of water sampling points collected in the study area and the hydrogeological profile of the Oujiayuan A to Shangwengshao $\mathrm{A}^{\prime}$ section (modified after [22]).

is placed in a container containing a water bath and ice, and then, the sensor is placed in a medium (air or water in a temperature-controlled bath) at a known temperature. This temperature may be measured using a certified thermometer.
(2) Oxygen calibration: using a clean sensor, occasionally check the $0 \%$ Sat value by immersing the sensor in a sulphite solution in water (sulphite concentration $<2 \%$ by weight). If there is a zero error, perform a complete calibration of the 
TABLE 1: Water samples collected in the study area.

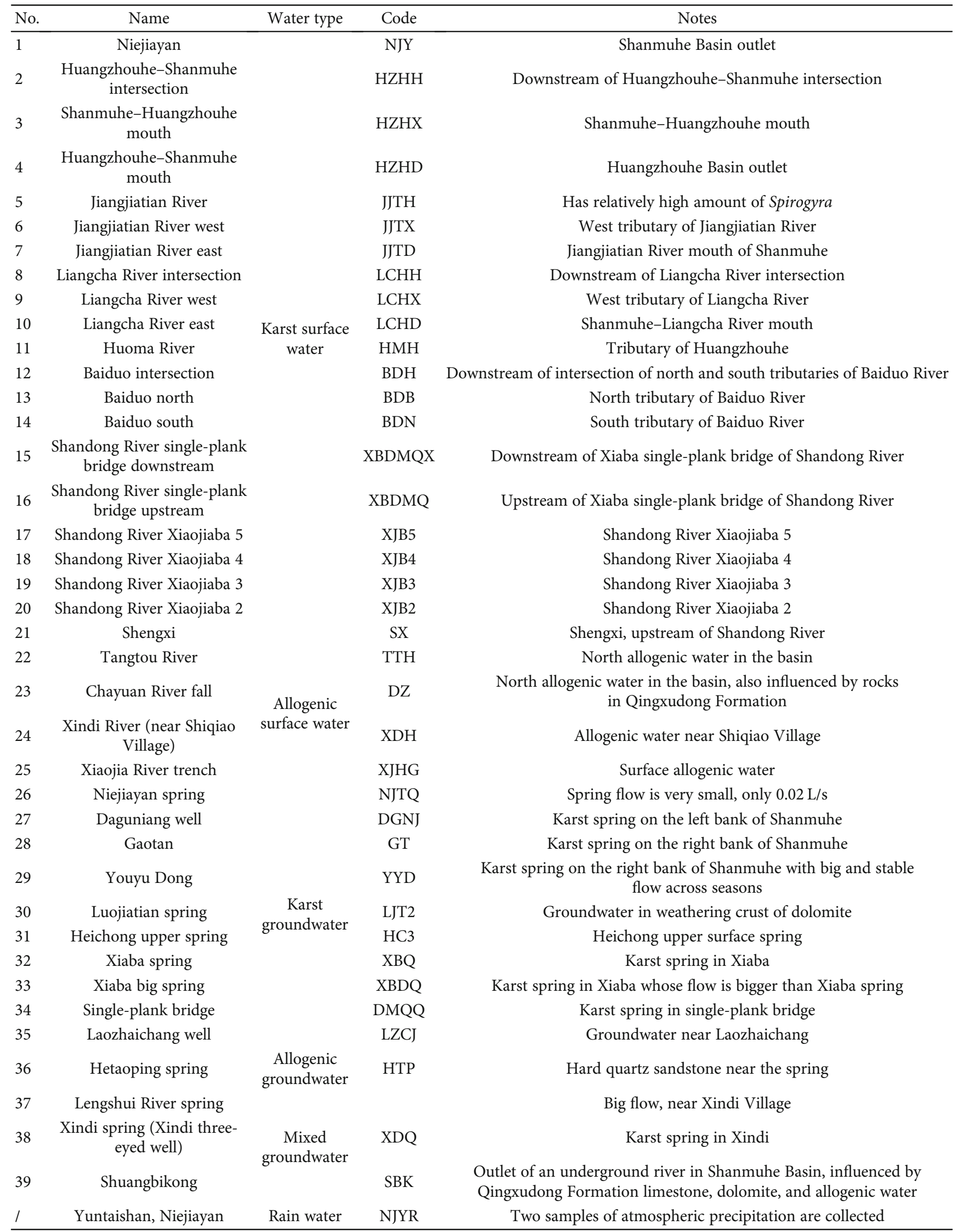


sensor. The 2-point calibration is performed using a sulphite solution (for the offset); then, after rinsing and drying, the sensor's gain is determined by exposing the sensor to humid, oxygen-saturated air. (3) The calibration of the conductivity sensor is a 2-step process: step 1 (offset): the sensor is exposed to air; step 2 (gain): the sensor is placed in a buffer solution of known conductivity. (4) The calibration of the $\mathrm{pH}$ sensor is a 2-step process: step 1 (offset): the sensor is placed in a $\mathrm{pH} 7.01$ buffer solution; step 2 (gain): the sensor is placed in a $\mathrm{pH} 4.01$ (or 9.01 or 10.01) buffer solution. The concentration of $\mathrm{HCO}_{3}$ and $\mathrm{Ca}^{2+}$ in water was measured by alkalinity meter and hardness meter produced by Merck Company, Germany, respectively. The accuracy is $0.1 \mathrm{mmol} / \mathrm{L}$ and $2 \mathrm{mg} / \mathrm{L}$.

Cationic water samples were collected by $50 \mathrm{~mL}$ highdensity polyethylene plastic bottles cleaned before, and anionic water samples were collected by $100 \mathrm{~mL}$ highdensity polyethylene plastic bottles. Among them, cationic water was acidified with $1: 1 \mathrm{HNO}_{3}$ until $\mathrm{pH}<2$. The cap was tightened and sealed with adhesive tape. The above samples were sealed and stored in the incubator at low temperature about $4^{\circ} \mathrm{C}$ and then brought back to the laboratory for analysis and determination.

3.2. Water Sample Analysis. The analysis of water samples mainly includes the main physical and chemical indexes (Table 2).

Anions were determined by ICS 90 type ion chromatograph produced by Dionex Company in the United States, while cations were determined by ICP-OES with a detection accuracy of $0.01 \mathrm{mg} / \mathrm{L}$ (relative standard deviation $<2 \%$ ).

Calcite saturation index (SIc), dolomite saturation index (SId), and partial pressure of carbon dioxide $\left(P_{\mathrm{CO}_{2}}\right)$ were calculated on Phreeqc and Watspec software by using $T$, $\mathrm{pH}$, and main ion concentrations of water samples.

The above tests were completed in the Water Chemical Analysis Laboratory of Southwest University and the State Key Laboratory of Environmental Geochemistry, Institute of Geochemistry, Chinese Academy of Sciences.

\section{Results}

\subsection{Hydrochemical Characteristics}

4.1.1. Hydrochemical Types. In order to study the hydrochemical types of surface water and groundwater in the Shanmuhe Dolomite Basin, Shibing, Guizhou, the corresponding Piper triangle diagram was made according to the ion content. The Piper diagram can better illustrate the composition and distribution characteristics of ions in water and can also distinguish the source of major and minor ions in water and the control of rock weathering.

From the Piper diagram (Figure 2) of the study area, $\mathrm{HCO}_{3}{ }^{-}$is the main anion in the karst surface water and groundwater. Its average values are $236.6 \mathrm{mg} / \mathrm{L}$ and $336.1 \mathrm{mg} / \mathrm{L}$, accounting for $91.7 \%$ and $93.7 \%$ of the total anions, respectively. The concentration and proportion of $\mathrm{HCO}_{3}{ }^{-}$in groundwater are higher than those in surface water, which is related to its longer water-rock interaction time. $\mathrm{Ca}^{2+}$ and $\mathrm{Mg}^{+}$are the main cations in karst surface water and groundwater of the study area. The average concentration of $\mathrm{Ca}^{2+}$ in surface water and groundwater is $45 \mathrm{mg} / \mathrm{L}$ and $65 \mathrm{mg} / \mathrm{L}$, respectively, accounting for $63.71 \%$ and $65.24 \%$ of the total cations, and the average concentration of $\mathrm{Mg}^{+}$in the surface water and groundwater is $25 \mathrm{mg} / \mathrm{L}$ and $32 \mathrm{mg} / \mathrm{L}$, respectively, accounting for $32.50 \%$ and $34.84 \%$ of the total cations, respectively. The remaining ions only account for less than 3\%. Therefore, the chemical types of karst surface water and groundwater in the study area are $\mathrm{HCO}_{3}-\mathrm{Ca} \cdot \mathrm{Mg}$. The concentrations of $\mathrm{Ca}^{2+}, \mathrm{Mg}^{2+}$, and $\mathrm{HCO}_{3}{ }^{-}$are closely related to karstification, reflecting the influence of dolomite dissolution on hydrochemical characteristics in the study area.

The ion content of surface water and groundwater in the allogenic water is very low, with $\mathrm{HCO}_{3}{ }^{-}$as the main anion, the average value of which is $36.6 \mathrm{mg} / \mathrm{L}$ and $18.3 \mathrm{mg} / \mathrm{L}$, accounting for $71.96 \%$ and $69.48 \%$ of the total anion, while the average concentration of $\mathrm{Ca}^{2+}$ as the main cation is $13 \mathrm{mg} / \mathrm{L}$ and $6 \mathrm{mg} / \mathrm{L}$, accounting for $74.29 \%$ and $64.28 \%$ of the total cation, respectively, and the $\mathrm{Mg}^{2+}$ content is very low. The hydrochemical type of the allogenic water in the study area is $\mathrm{HCO}_{3}-\mathrm{Ca}$, but the proportion of $\mathrm{Na}^{+}, \mathrm{K}^{+}$, $\mathrm{NO}_{3}{ }^{-}, \mathrm{Cl}^{-}$, and $\mathrm{SO}_{4}{ }^{2-}$ is higher than that of karst surface water and groundwater. Only low concentration of $\mathrm{Ca}^{2+}, \mathrm{NO}_{3}{ }^{-}$, and $\mathrm{SO}_{4}{ }^{2-}$ was detected in atmospheric precipitation.

Gibbs' semilogarithmic coordinate diagrams can be used to analyze the main sources of hydrochemistry of rivers [23]. As shown in Figure 3, the longitudinal coordinate of Gibbs diagram is TDS (logarithmic representation, $\mathrm{mg} / \mathrm{L}$ ), and the horizontal ordinate represents the mass concentration ratio of cationic $\mathrm{Na}^{+} /\left(\mathrm{Na}^{+}+\mathrm{Ca}^{2+}\right)$ and anionic $\mathrm{Cl}^{-} /\left(\mathrm{Cl}^{-}+\mathrm{HCO}_{3}{ }^{-}\right)$, respectively. Almost all the ionic component values of surface water in the world fall into the imaginary frame in the figure. Points with low TDS and high $\mathrm{Na}^{+} /\left(\mathrm{Na}^{+}+\mathrm{Ca}^{2+}\right)$, $\mathrm{Cl}^{-} /\left(\mathrm{Cl}^{-}+\mathrm{HCO}_{3}{ }^{-}\right)$ratios (close to 1 ) are distributed in the lower right corner, reflecting regional precipitation control; points with medium TDS and $\mathrm{Na}^{+} /\left(\mathrm{Na}^{+}+\mathrm{Ca}^{2+}\right), \mathrm{Cl}^{-} /\left(\mathrm{Cl}^{-}+\mathrm{HCO}_{3}{ }^{-}\right)$ ratios $(<0.5)$ are located on the left side of the diagram, reflecting the influence of rock weathering; and higher TDS and $\mathrm{Na}^{+} /\left(\mathrm{Na}^{+}+\mathrm{Ca}^{2+}\right), \mathrm{Cl}^{-} /\left(\mathrm{Cl}^{-}+\mathrm{HCO}_{3}{ }^{-}\right)$ratios (close to 1 ) reflect the influence of evaporation and concentration.

The diagram indicates that the distribution of TDS in Shibing Shanmuhe Dolomite Basin is as follows: karst surface water $164.4-282.4 \mathrm{mg} / \mathrm{L}$ with average $210.0 \mathrm{mg} / \mathrm{L}$, karst groundwater $234.8-341.8 \mathrm{mg} / \mathrm{L}$ with average $290.7 \mathrm{mg} / \mathrm{L}$, and allogenic water $21.5-88.8 \mathrm{mg} / \mathrm{L}$ with average $42 \mathrm{mg} / \mathrm{L}$. The $\mathrm{Na}^{+} /\left(\mathrm{Na}^{+}+\mathrm{Ca}^{2+}\right)$ value is $0-0.034$ for karst surface water with average $0.009,0.003-0.057$ for karst groundwater with average 0.013 , and $0.013-0.212$ for allogenic water with average 0.118 . The ratio of $\mathrm{Cl}^{-} /\left(\mathrm{Cl}^{-}+\mathrm{HCO}_{3}{ }^{-}\right)$is $0-0.183$ for karst surface water with average $0.017,0.004-0.032$ for karst groundwater with average 0.016 , and $0.008-0.366$ for allogenic water with average 0.087 . All water points fall within the range of $\mathrm{Na}^{+} /\left(\mathrm{Na}^{+}+\mathrm{Ca}^{2+}\right)$ or $\mathrm{Cl}^{-} /\left(\mathrm{Cl}^{-}+\mathrm{HCO}_{3}{ }^{-}\right)$ratios less than 0.5 and are distributed on the left middle side of the figure, reflecting that surface water and groundwater in Shibing dolomite karst basin belong to the "rock weathering type." Ion composition in water mainly comes from the weathering process of rocks, and weathering of rocks has a significant 
TABLE 2: Analyzed items and the methods used in water samples collected in the study area.

\begin{tabular}{|c|c|c|c|c|}
\hline \multirow[b]{2}{*}{ Items } & \multicolumn{2}{|c|}{ Types } & \multirow[t]{2}{*}{$\begin{array}{l}\text { Indexes for indirect } \\
\text { calculation }\end{array}$} & \multirow[t]{2}{*}{ Methods } \\
\hline & $\begin{array}{l}\text { Direct } \\
\text { measurement }\end{array}$ & $\begin{array}{l}\text { Indirect } \\
\text { calculation }\end{array}$ & & \\
\hline$T$ & $\sqrt{ }$ & & & Automatic monitoring \\
\hline $\mathrm{pH}$ & $\sqrt{ }$ & & & Automatic monitoring \\
\hline EC & $\sqrt{ }$ & & & Automatic monitoring \\
\hline $\mathrm{K}^{+}$ & & & & Samples were manually collected and brought back to lab for ICP-OES analysis \\
\hline $\mathrm{Na}^{+}$ & & & & Samples were manually collected and brought back to lab for ICP-OES analysis \\
\hline $\mathrm{Ca}^{2+}$ & & & & $\begin{array}{l}\text { When samples were manually collected, use } \mathrm{Ca}^{2+} \text { cells for titration directly on the } \\
\text { field and brought back to lab for ICP-OES analysis }\end{array}$ \\
\hline $\mathrm{Mg}^{2+}$ & & & & Samples were manually collected and brought back to lab for ICP-OES analysis \\
\hline $\mathrm{Cl}^{-}$ & & & & $\begin{array}{l}\text { Samples were manually collected and brought back to lab for ion } \\
\text { chromatography analysis }\end{array}$ \\
\hline $\mathrm{SO}_{4}^{2-}$ & & & & $\begin{array}{l}\text { Samples were manually collected and brought back to lab for ion } \\
\text { chromatography analysis }\end{array}$ \\
\hline $\mathrm{NO}_{3}^{-}$ & & & & $\begin{array}{l}\text { Samples were manually collected and brought back to lab for ion } \\
\text { chromatography analysis }\end{array}$ \\
\hline $\mathrm{HCO}_{3}^{-}$ & & & & $\begin{array}{l}\text { When samples were manually collected, use alkalinity titrating cells for titration } \\
\text { directly on the field }\end{array}$ \\
\hline$P_{\mathrm{CO}_{2}}$ & & $\sqrt{ }$ & $\begin{array}{c}T, \mathrm{pH}, \\
\text { concentration of } \\
\text { key ions }\end{array}$ & Calculated by Phreeqc and Watspec \\
\hline $\mathrm{SI}_{\mathrm{C}}$ & & $\sqrt{ }$ & $\begin{array}{c}T, \mathrm{pH}, \\
\text { concentration of } \\
\text { key ions }\end{array}$ & Calculated by Phreeqc and Watspec \\
\hline $\mathrm{SI}_{\mathrm{D}}$ & & $\sqrt{ }$ & $\begin{array}{c}T, \mathrm{pH}, \\
\text { concentration of } \\
\text { key ions }\end{array}$ & Calculated by Phreeqc and Watspec \\
\hline
\end{tabular}

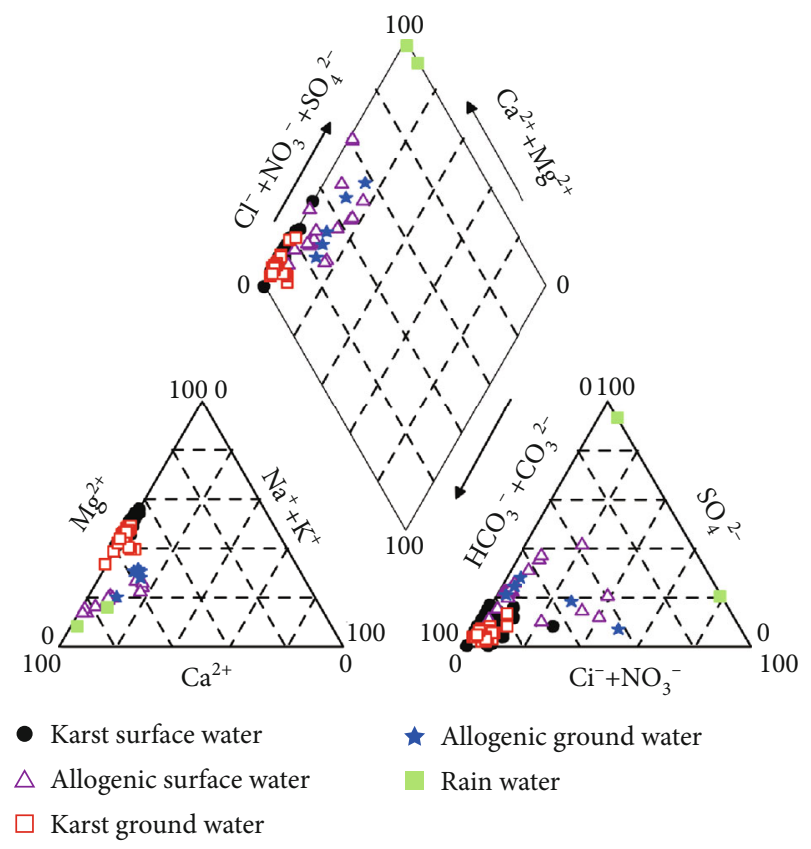

Figure 2: Chemistry Piper diagram of the surface water, underground water, and rain water in Shanmuhe Catchment. impact on the hydrochemistry in this area. The ratios of $\mathrm{Na}^{+} /\left(\mathrm{Na}^{+}+\mathrm{Ca}^{2+}\right)$ or $\mathrm{Cl}^{-} /\left(\mathrm{Cl}^{-}+\mathrm{HCO}_{3}{ }^{-}\right)$in some samples of allogenic water are higher, but the ratio is less than 0.5 , reflecting that some water points of allogenic water may also be affected by atmospheric precipitation.

4.1.2. Overall Hydrochemical Characteristics. The composition of water system in Shibing dolomite karst basin is divided into atmospheric precipitation, karst surface water, karst groundwater, and allogenic water.

(1) Atmospheric Precipitation. Two precipitation samples were obtained in the basin. The $\mathrm{pH}$ of the precipitation in the basin is 5.0 and 5.3, respectively, with an average value of 5.2. The conductivity of the two rainfalls was $22 \mu \mathrm{S} / \mathrm{cm}$ and $25 \mu \mathrm{S} / \mathrm{cm}$, respectively, with an average of $23 \mu \mathrm{S} / \mathrm{cm}$. The concentration of ions in precipitation is very low, even some ions are not detected, only $\mathrm{Ca}^{2+}$ and $\mathrm{SO}_{4}{ }^{2-}$ with the mean values of $0.03 \mathrm{mmol} / \mathrm{L}$ and $0.05 \mathrm{mmol} / \mathrm{L}$, respectively. The concentration of $\mathrm{Mg}^{2+}, \mathrm{K}^{+}$, and $\mathrm{Cl}^{-}$is very low, and $\mathrm{Na}^{+}$and $\mathrm{HCO}_{3}{ }^{-}$cannot be detected.

(2) Karst Surface Water. The karst surface water in the basin was taken from the main trunk and tributaries of the Shanmuhe from the upstream to the downstream of the basin. 

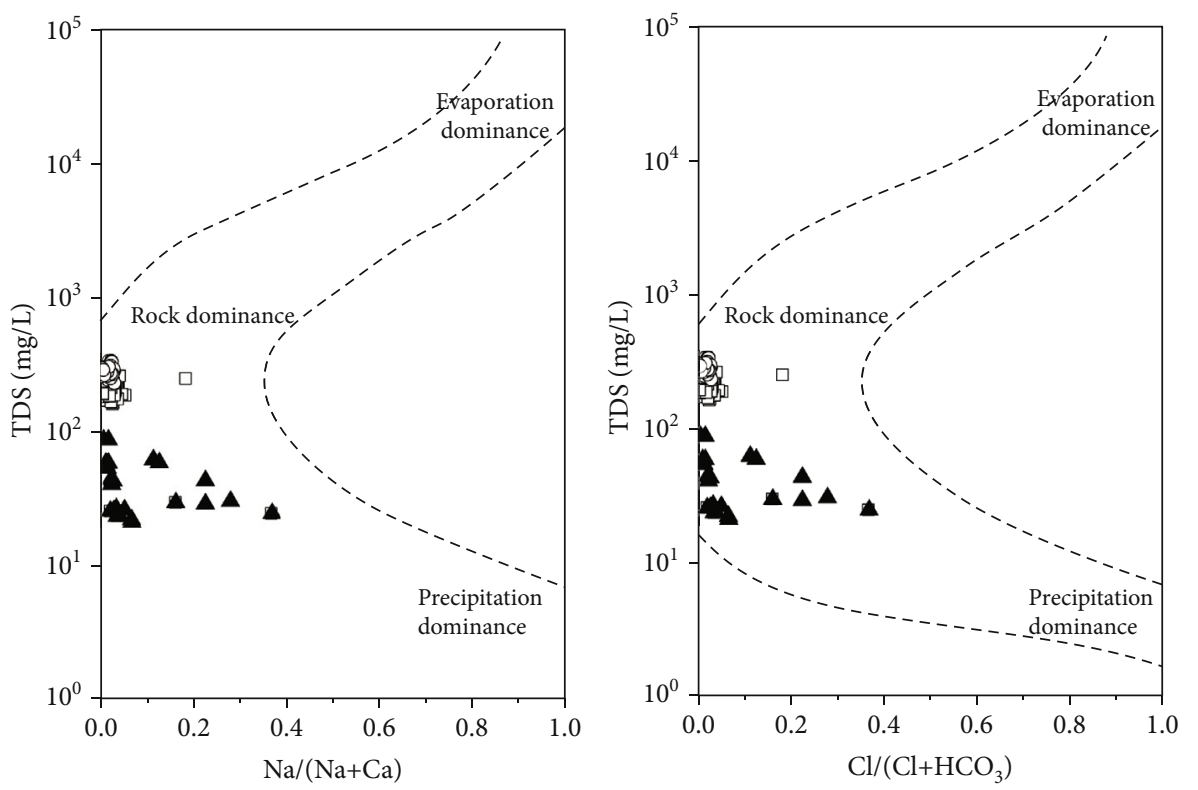

$\square$ Karst surface water
$\bigcirc$ Karstground water
A Allogenic water

Figure 3: Gibbs graphs of surface and underground waters in Shanmuhe Dolomite Catchment.

The variation range of water temperature is $4.1-24.0^{\circ} \mathrm{C}$. The standard deviation (STD) and coefficient of variation (CV) are large, indicating that the change of water temperature is obvious, mainly affected by the change of surface atmospheric temperature. The $\mathrm{pH}$ ranges from 7.92 to 9.44 , with an average of 8.67 , belonging to alkaline water. The conductivity ranges from $320 \mu \mathrm{s} / \mathrm{cm}$ to $595 \mu \mathrm{s} / \mathrm{cm}$, with an average of $374 \mu \mathrm{s} / \mathrm{cm}$. The variation range is large, but the $\mathrm{CV}$ is only $9.15 \%$. This indicates that the conductivity in surface water is relatively stable. The concentrations of $\mathrm{Ca}^{2+}$ and $\mathrm{Mg}^{2+}$ in surface water are $0.70 \sim 1.55 \mathrm{mmol} / \mathrm{L}$ and $0.63 \sim 1.49 \mathrm{mmol} / \mathrm{L}$, respectively. The average values are $1.12 \mathrm{mmol} / \mathrm{L}$ and $1.02 \mathrm{mmol} / \mathrm{L}$, respectively. The concentration of the two ions has little change, and the ion concentration is at the same level. The variation range of $\mathrm{Mg}^{2+} / \mathrm{Ca}^{2+}$ is $0.64 \sim 1.30$ with the average of 0.92 , which is close to 1 , and the variation is not significant, indicating that dolomite dissolution is dominant in the basin. Meanwhile, the mean value of $\left(\mathrm{Ca}^{2+}+\mathrm{Mg}^{2+}\right) / \mathrm{HCO}_{3}^{-}$is 0.56 , which is equivalent to $2 \mathrm{HCO}_{3}{ }^{-}=\mathrm{Ca}^{2+}+\mathrm{Mg}^{2+}$, indicating that carbonate controls the strong dissolution of dolomite. The contents of $\mathrm{K}^{+}$and $\mathrm{Na}^{+}$ions are very low, and the mean sum of them is only $0.03 \mathrm{mmol} / \mathrm{L}$. The anion is mainly $\mathrm{HCO}_{3}{ }^{-}$with a value of $2.90-5.20 \mathrm{meq} / \mathrm{L}$, a mean of $3.87 \mathrm{meq} / \mathrm{L}$, and a CV of $11.86 \%$. This indicates that the temporal and spatial distribution of $\mathrm{HCO}_{3}{ }^{-}$concentration of surface karst water in the basin is relatively stable under the same climate and geological background. $\mathrm{SO}_{4}{ }^{2-}, \mathrm{Cl}^{-}$, and $\mathrm{NO}_{3}{ }^{-}$ions are all very low, and the sum of them accounts for less than $10 \%$ of the anions.

(3) Karst Groundwater. The temperature of karst groundwater in the basin ranges from 11.7 to $23.3^{\circ} \mathrm{C}$, with an average of $16.7^{\circ} \mathrm{C}$, and the variation range is less than that of surface water. The $\mathrm{pH}$ ranges from 7.15 to 8.82 , with an average of 7.74. The conductivity ranges from $219 \mu \mathrm{s} / \mathrm{cm}$ to $612 \mu \mathrm{s} / \mathrm{cm}$, with an average of $496.8 \mu \mathrm{s} / \mathrm{cm}$. Compared with the karst surface water, the groundwater has lower $\mathrm{pH}$ and higher conductivity. On the one hand, lower $\mathrm{pH}$ promotes dissolution; on the other hand, groundwater has a relatively long time of rock-water interaction, which leads to higher ion concentration in groundwater. $\mathrm{Ca}^{2+}, \mathrm{Mg}^{2+}$, and $\mathrm{HCO}_{3}{ }^{-}$are the main ions in the groundwater, and the average concentrations are $1.57 \mathrm{mmol} / \mathrm{L}, 1.28 \mathrm{mmol} / \mathrm{L}$, and $5.25 \mathrm{meq} / \mathrm{L}$, respectively. The concentration of $\mathrm{Ca}^{2+}$ is slightly higher than that of $\mathrm{Mg}^{2+}$. The range of $\mathrm{Mg}^{2+} / \mathrm{Ca}^{2+}$ varies from 0.49 to 1.0 , with an average of 0.81 , which may be the result of ratio of limestone dissolution in groundwater source. The average value of $\left(\mathrm{Ca}^{2+}+\mathrm{Mg}^{2+}\right) / \mathrm{HCO}_{3}{ }^{-}$is 0.55 , which is equivalent to $2 \mathrm{HCO}_{3}{ }^{-}=\mathrm{Ca}^{2+}+\mathrm{Mg}^{2+}$, indicating that carbonate controls the strong dissolution of dolomite in the basin. Similar to karst surface water, $\mathrm{K}^{+}, \mathrm{Na}^{+}, \mathrm{SO}_{4}{ }^{2-}, \mathrm{Cl}^{-}$, and $\mathrm{NO}_{3}{ }^{-}$ions in karst groundwater are very low. This is mainly because, on the one hand, Shibing Shanmuhe Basin is a world natural heritage site with good ecological environment and low ion composition of precipitation, which can neglect the input of surface water and groundwater in the basin; on the other hand, the lithology of the study area is dominated by dolomite.

(4) Allogenic Water. The nonkarst area in the basin is mainly located in the northwest part. Its strata and lithology mainly include the clay shale of Cambrian Palang Formation, the carbonaceous shale and sandstone of Bianmachong Formation, the siliceous rock and carbonaceous shale of Sinian Laobao Formation, and the dolomite, argillaceous dolomite, 
shale, and claystone of Doushantuo Formation. The $\mathrm{pH}$ of the allogenic water ranges from 6.68 to 8.21 , with an average of 7.54, which is lower than that of the karst water. The conductivity is only $42.9-181.2 \mu \mathrm{S} / \mathrm{cm}$, which is lower than that of the karst water. $\mathrm{Ca}^{2+}$ and $\mathrm{HCO}_{3}{ }^{-}$are the main ions, and their average values are $0.26 \mathrm{mmol} / \mathrm{L}$ and $0.49 \mathrm{mmol} / \mathrm{L}$, respectively. Then, the concentration of $\mathrm{Mg}^{2+}$ and $\mathrm{SO}_{4}{ }^{2-}$ is $0.08 \mathrm{mmol} / \mathrm{L}$, the average concentration of $\mathrm{NO}_{3}{ }^{-}+\mathrm{Cl}^{-}$is $0.09 \mathrm{mmol} / \mathrm{L}$, and $\mathrm{Na}^{+}+\mathrm{K}^{+}$is $0.06 \mathrm{mmol} / \mathrm{L}$. The average values of $\mathrm{Mg}^{2+} / \mathrm{Ca}^{2+}$ and $\left(\mathrm{Ca}^{2+}+\mathrm{Mg}^{2+}\right) / \mathrm{HCO}_{3}{ }^{-}$are 0.34 and 0.77 , respectively, which are not consistent with the results of carbonate rock dissolution.

\subsection{Variation Rules of Hydrochemistry}

4.2.1. Spatial Variation of Hydrochemistry. Dolomite is the main lithology in Shibing Shanmuhe Basin, but there are many different strata in the basin. In the northwest part of the basin, it is influenced by noncarbonate rocks such as sandstone and shale of Cambrian Bianmachong Formation and Palang Formation as well as impure carbonate rocks of Qingxudong Formation and also impure dolomite of Shilengshui Formation. The distribution of impure dolomite in Shilengshui Formation and pure dolomite in Loushanguan Formation is dominant in the whole basin, and the Huangzhouhe subbasin is the typical pure dolomite basin. Because the basin is dominated by surface rivers, there are few big springs and many small springs, but the water quantity of springs is small. Therefore, the authors only discuss the spatial variation characteristics of surface water.

Samples of river water were collected in the main stream and tributaries of the Shibing Shanmuhe Basin. Considering that the main stream, in the lower reaches of the Shibing Shanmuhe Basin, is affected by the river water from the upper reaches, while the tributary river water is not affected by the upper main stream, its hydrochemistry represents the characteristics of the subbasin; the distribution of lithology is also taken into account. Therefore, the hydrochemical data of the tributaries and tributary water sources of the Shanmuhe are presented below for analysis. No. 3, which represents the main stream of Shanmuhe, No. 4, which represents Huangzhouhe Basin, No. 6, which represents Jiangjiatian tributary influenced by pure dolomite, No. 9, which represents the west of Liangcha River, No. 10, which represents the east of Liangcha River, Nos. 15-20 (mean value) and No. 21 of Dolomite Basin in Shandong River, and Nos. 22-24 of allogenic water in the upper and northwest of the basin were selected for analysis (the distribution of sample points is shown in Figure 1).

Figure 4 shows that $\mathrm{EC}, \mathrm{Ca}^{2+}, \mathrm{Mg}^{2+}, \mathrm{HCO}_{3}{ }^{-}, \mathrm{Mg}^{2+} / \mathrm{Ca}^{2+}$, and $\mathrm{Mg}^{2+} / \mathrm{HCO}_{3}{ }^{-}$have similar spatial variation, mainly due to different lithology controls. The average EC concentration of the allogenic water (No. 22-24 sample points) northeast of the upper reaches of the basin was $45 \pm 3 \mu \mathrm{S} / \mathrm{cm}, 89 \pm 5 \mu \mathrm{S} /$ $\mathrm{cm}$, and $181 \mu \mathrm{S} / \mathrm{cm}$, respectively; the average $\mathrm{Ca}^{2+}$ concentration is $0.15 \pm 0.05 \mathrm{mmol} / \mathrm{L}, \quad 0.36 \pm 0.05 \mathrm{mmol} / \mathrm{L}$, and $0.66 \mathrm{mmol} / \mathrm{L}$; the average $\mathrm{Mg}^{2+}$ concentration is $0.05 \pm 0.01$ $\mathrm{mmol} / \mathrm{L}, 0.09 \pm 0.01 \mathrm{mmol} / \mathrm{L}$, and $0.14 \mathrm{mmol} / \mathrm{L}$; the average $\mathrm{HCO}_{3}{ }^{-}$concentration is $0.28 \pm 0.1 \mathrm{mmol} / \mathrm{L}, 0.64 \pm 0.21$ $\mathrm{mmol} / \mathrm{L}$, and $1.40 \mathrm{mmol} / \mathrm{L}$; the concentration of these ions is significantly lower than that of the surface river sampling points in the karst area. The concentration of No. 24 sample is slightly higher than that of No. 22 and No. 23, mainly because No. 24 is affected not only by clay shale of the Palang Formation but also by impure carbonate rocks of the Qingxudong Formation. The flow of No. 22 and No. 23 samples reaches No. 10 after passing through the dolomite area, and No. 24 flows into the Shanmuhe at No. 9. The concentrations of $\mathrm{EC}, \mathrm{Ca}^{2+}, \mathrm{Mg}^{2+}$, and $\mathrm{HCO}_{3}{ }^{-}$are significantly increased, mainly because the $\mathrm{SI}_{\mathrm{C}}$ and $\mathrm{SI}_{\mathrm{D}}$ of the allogenic water are both lower than 0 and have strong dissolution capacity, which can dissolve the hosting carbonate rocks. $\mathrm{SI}_{\mathrm{C}}$ and $\mathrm{SI}_{\mathrm{D}}$ of surface rivers in all karst areas are $>0.8$, indicating that carbonate deposits will occur when they reach supersaturation. In addition, the water at the No. 15-21 sample points in the northeast of the upper reaches of the basin will also affect the ion concentration at the No. 10 sample point. Due to the influence of the upstream allogenic water, the concentrations of EC, $\mathrm{Ca}^{2+}, \mathrm{Mg}^{2+}$, and $\mathrm{HCO}_{3}{ }^{-}$at No. 9 and No. 10 sample points are lower than those at other karst surface rivers. Generally, the upstream ion concentration is lower than that in the middle and lower reaches. The small basin where No. 4, No. 6, and No. 21 sample points are located is pure dolomite, and the average $\mathrm{HCO}_{3}{ }^{-}$concentration is $4.36 \pm$ $0.3 \mathrm{mmol} / \mathrm{L}, 4.39 \pm 0.16 \mathrm{mmol} / \mathrm{L}$, and $4.23 \pm 0.33 \mathrm{mmol} / \mathrm{L}$, respectively; the average $\mathrm{Mg}^{2+} / \mathrm{Ca}^{2+}$ concentration is $0.98 \pm$ $0.15,1.0 \pm 0.14$, and $0.96 \pm 0.13$, respectively. No. 3, 9, and 10 sample points belong to impure dolomite basins. The average $\mathrm{HCO}_{3}{ }^{-}$concentration is $3.71 \pm 0.33 \mathrm{mmol} / \mathrm{L}, 3.6 \pm$ $0.34 \mathrm{mmol} / \mathrm{L}, 3.38 \pm 0.23 \mathrm{mmol} / \mathrm{L}$, and $4.07 \pm 0.08 \mathrm{mmol} / \mathrm{L}$, and the average $\mathrm{Mg}^{2+} / \mathrm{Ca}^{2+}$ concentration is $0.91 \pm 0.05$, $0.85 \pm 0.07,0.91 \pm 0.05$, and $0.94 \pm 0.03$, respectively. These results indicate that the concentrations of $\mathrm{HCO}_{3}{ }^{-}$and $\mathrm{Mg}^{2+} / \mathrm{Ca}^{2+}$ in pure dolomite basin are generally higher than those in dolomite and limestone basin. It shows that although the dissolution rate of dolomite is slower than that of limestone, its higher solubility makes it produce more $\mathrm{HCO}_{3}{ }^{-}$.

4.2.2. Monthly Variation of Hydrochemistry. In order to illustrate the hydrochemical monthly variation characteristics of typical dolomite karst basins in subtropical zone, two representative samples (No. 4 and No. 29) were selected, of which No. 4 was the overall outlet of Huangzhouhe Basin, representing the surface water of dolomite karst basin, and No. 29 YYD was a karst spring representing the groundwater of dolomite karst basin. In Figure 5, the main hydrochemical analysis of water samples taken monthly at these two sampling points is reported. According to the analysis above, the contents of $\mathrm{K}^{+}, \mathrm{Na}^{+}, \mathrm{SO}_{4}{ }^{2-}, \mathrm{Cl}^{-}$, and $\mathrm{NO}_{3}{ }^{-}$ions in the basin are very low. Therefore, the monthly variation characteristics of $\mathrm{Ca}^{2+}, \mathrm{Mg}^{2+}$, and $\mathrm{HCO}_{3}{ }^{-}$and related indicators in the basin are discussed here.

From Figure 5, it can be seen that the $\mathrm{pH}$ of the outlet water of Huangzhouhe varies from 8.40 to 8.80 , which is alkaline, low in rainy season and high in dry season. The conductivity varies between $397 \mu \mathrm{s} / \mathrm{cm}$ and $424 \mu \mathrm{s} / \mathrm{cm}$, and it is smaller in rainy season than in dry season, but the variation coefficient is 0.03 , which indicates that the dilution effect is 

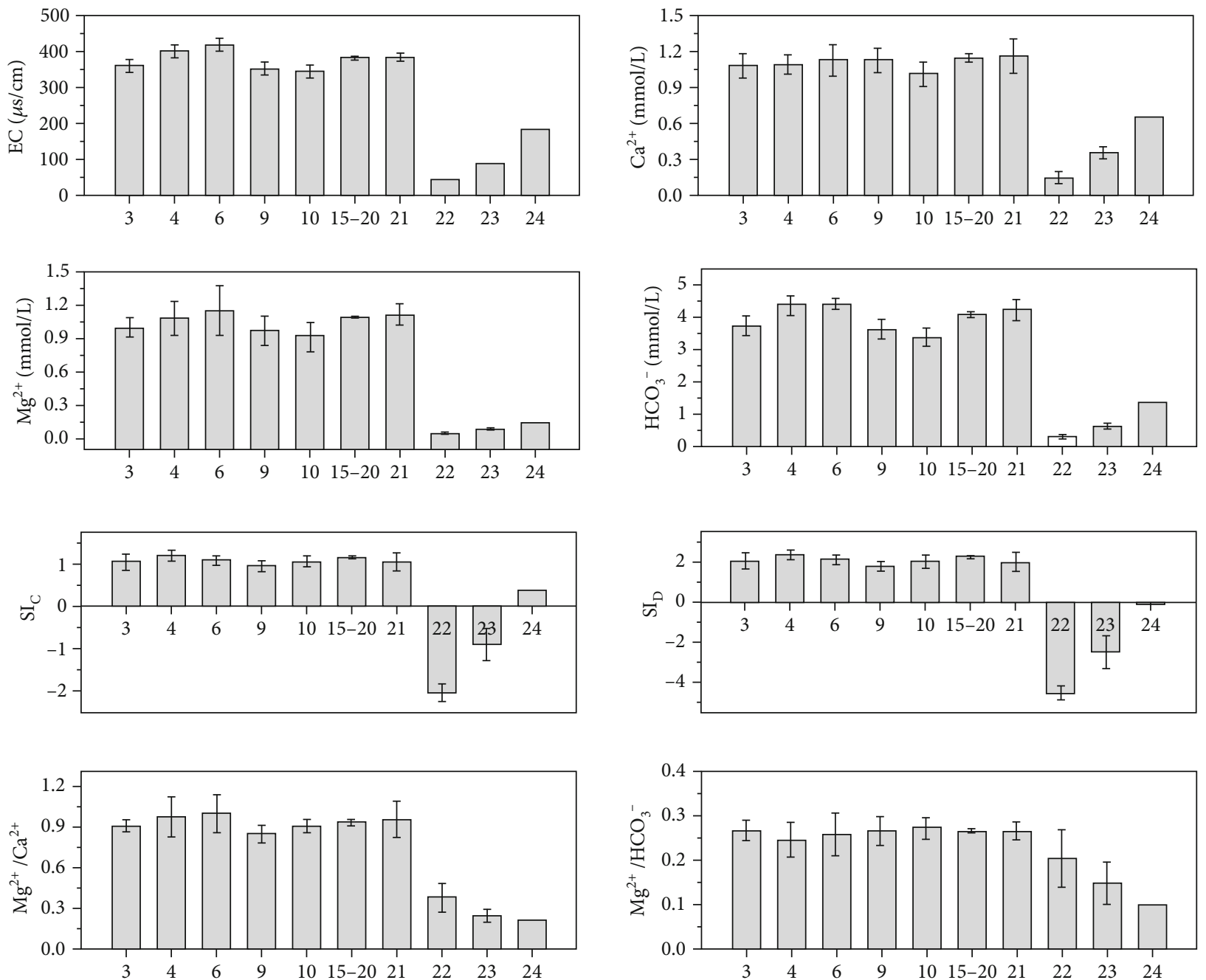

FIgURE 4: Space variation of the hydrochemistry of waters in Shanmuhe Catchment.

not obvious in rainy season. Correspondingly, the changes of $\mathrm{Ca}^{2+}, \mathrm{Mg}^{2+}$, and $\mathrm{HCO}_{3}{ }^{-}$are also small, and their concentrations are between $42-54 \mathrm{mg} / \mathrm{L}, \quad 20-31 \mathrm{mg} / \mathrm{L}$, and $238-$ $347 \mathrm{mg} / \mathrm{L}$. The variation coefficients are $0.07,0.17$, and 0.11 , respectively. The variation rule is that the concentration in rainy season is smaller than that in dry season. The saturation indexes $\mathrm{SI}_{\mathrm{C}}$ and $\mathrm{SI}_{\mathrm{D}}$ in river water have the same trend of change, and the change is not significant, and they reach the state of supersaturation every month. The results show that although the dissolution rate of dolomite is relatively slow, it may still reach dissolution equilibrium at the basin scale. Shibing belongs to the subtropical monsoon climate zone. Rainfall and heat occur in the same period. Generally, high temperature and strong microbial activity in the rainy season promote dissolution and increase ion production, but at the same time, the increase of precipitation will dilute various ions. However, there is little difference between ion concentrations in rainy season and in dry season, and the ion concentration is relatively stable. That is to say, the large variation of flow rate does not cause the large variation of ion concentration, which indicates that the variation of flow rate is much larger than that of ion concentration. On the one hand, water-rock interaction may be the main factor affecting ion concentration; on the other hand, it indicates that there may be chemical steady-state behavior at the outlet of Huangzhouhe Basin.

From Figure 6, it can be seen that the $\mathrm{pH}$ of YYD spring water at point No. 29 ranges from 7.40 to 7.89 , which is lower than that of the surface rivers. $\mathrm{EC}, \mathrm{Ca}^{2+}, \mathrm{Mg}^{2+}$, and $\mathrm{HCO}_{3}{ }^{-}$of the spring water are lower in rainy season than in dry season, and the maximum values all occur in dry season, but their variation coefficients are less than 0.1 , which is relatively stable in a hydrological year. Saturation indexes $\mathrm{SI}_{\mathrm{C}}$ and $\mathrm{SI}_{\mathrm{D}}$ have the same trend of change, and the change is not significant, and each month is greater than 0 , basically reaching saturation state. It is also evident that the groundwater of the dolomite reaches the dissolution equilibrium.

\subsection{Factors Influencing the Formation of Hydrochemistry in Dolomite Basin}

\subsubsection{Geological Background and Karstification Control}

(1) The Geochemical Effect of Carbonate Minerals on Main Ions. The dissolution reaction equation of carbonate dissolution limestone and dolomite can be expressed as follows: 


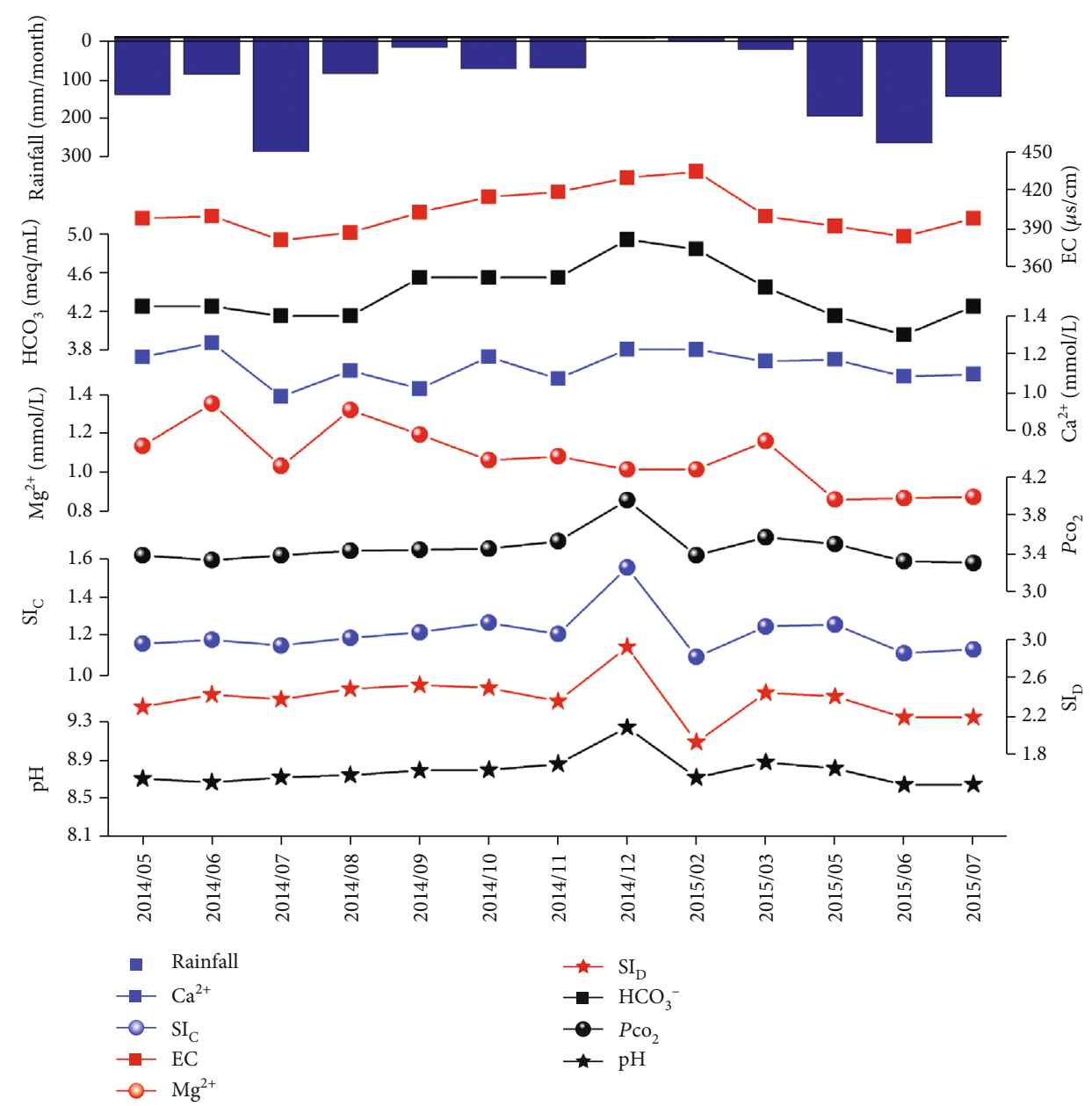

Figure 5: Monthly variation of the hydrochemistry of No. 4 water in outlet of Huangzhouhe Basin.

For limestone:

$$
\mathrm{CaCO}_{3}+\mathrm{H}_{2} \mathrm{CO}_{3} \Longleftrightarrow \mathrm{Ca}^{2+}+2 \mathrm{HCO}_{3}^{-}
$$

For dolomite:

$$
\mathrm{Mg}_{0.5} \mathrm{Ca}_{0.5} \mathrm{CO}_{3}+\mathrm{H}_{2} \mathrm{CO}_{3} \Longleftrightarrow \mathrm{Mg}_{0.5}{ }^{2+}+\mathrm{Ca}_{0.5}{ }^{2+}+2 \mathrm{HCO}_{3}^{-}
$$

Limestone and dolomite dissolve to form $\mathrm{Ca}^{2+}, \mathrm{Mg}^{2+}$, and $\mathrm{HCO}_{3}{ }^{-}$. In theory, $\left(\mathrm{Ca}^{2+}+\mathrm{Mg}^{2+}\right): \mathrm{HCO}_{3}{ }^{-}$molar ratio is $1: 2$. The samples of karst surface water $\left(\mathrm{Ca}^{2+}+\mathrm{Mg}^{2+}\right) / \mathrm{HCO}_{3}{ }^{-}$ in the basin are located near the $2: 1$ line of carbonate mineral dissolution reaction. Some of the samples are slightly higher and some are slightly lower (Figure 7). The concentration of $\mathrm{HCO}_{3}{ }^{-}$varies from 2.90 to $5.20 \mathrm{meq} / \mathrm{L}$. Most of the samples of the karst groundwater $\left(\mathrm{Ca}^{2+}+\mathrm{Mg}^{2+}\right) / \mathrm{HCO}_{3}{ }^{-}$fall slightly below the $2: 1$ line, and their $\mathrm{HCO}_{3}{ }^{-}$concentration ranges from 1.90 to $6.20 \mathrm{meq} / \mathrm{L}$. Karst surface water and groundwater have similar trends. Most of the water sample points are below the 2:1 line of carbonate rock, indicating that the surface water and groundwater in the basin are rich in $\mathrm{Ca}^{2+}$ and $\mathrm{Mg}^{2+}$, and carbonate rock (dolomite, limestone) is not the only source of $\mathrm{Ca}^{2+}$ and $\mathrm{Mg}^{2+}$ compared with $\mathrm{HCO}_{3}{ }^{-}$. The contribution of atmospheric precipitation to $\mathrm{Ca}^{2+}$ is $0.03 \mathrm{mmol} / \mathrm{L}, 0.003 \mathrm{mmol} / \mathrm{L}$ to $\mathrm{Mg}^{2+}$, and 0 to $\mathrm{HCO}_{3}{ }^{-}$. Even after precipitation correction, its contribution to surface water and groundwater is very weak, $\left(\mathrm{Ca}^{2+}+\mathrm{Mg}^{2+}\right)$ is still relatively enriched. The hydrochemical analysis in the basin shows that the concentration of $\mathrm{SO}_{4}{ }^{2-}$ is very low, and there is no sulfur-bearing stratum in the area, and sulfuric acid has little effect on the dissolution of carbonate rocks. The sample points of $\left(\mathrm{Ca}^{2+}+\mathrm{Mg}^{2+}\right) / \mathrm{HCO}_{3}{ }^{-}$in the allogenic water tend to the cationic side, which indicates that the contribution of allogenic water to $\mathrm{Ca}^{2+}$ and $\mathrm{Mg}^{2+}$ is more than that to $\mathrm{HCO}_{3}{ }^{-}$.

Because of the existence of limestone and impure dolomite in the basin, $\mathrm{Ca}^{2+}$ comes from both dolomite mineral dissolution and limestone mineral dissolution, while $\mathrm{Mg}^{2+}$ only comes from dolomite mineral dissolution. To clarify the relative contribution of limestone and dolomite dissolution, the relationship between $\mathrm{Mg}^{2+} / \mathrm{Ca}^{2+}$ in basin water is shown in Figure 8. When only limestone dissolves, assuming that limestone has small amount of $\mathrm{Mg}$ to replace $\mathrm{Ca}, \mathrm{Mg}^{2+} / \mathrm{Ca}^{2+}$ is much lower than 0.10 ; when the same amount of limestone and dolomite dissolves, $\mathrm{Mg}^{2+} / \mathrm{Ca}^{2+}=$ 0.33; the composition of dolomite increases against limestone, 


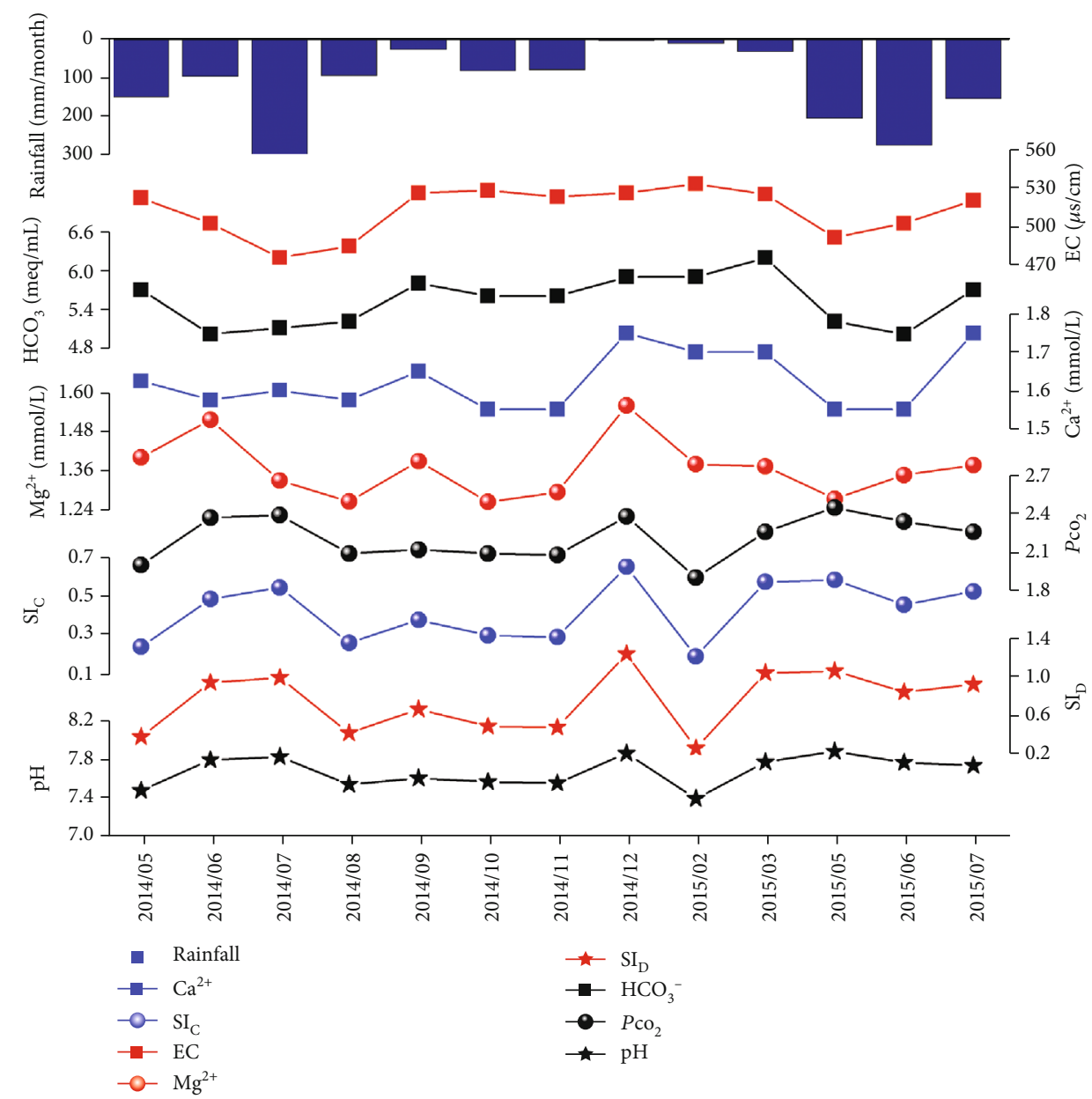

FIGURE 6: Monthly variation of the hydrochemistry of No. 29 water in YYD spring.

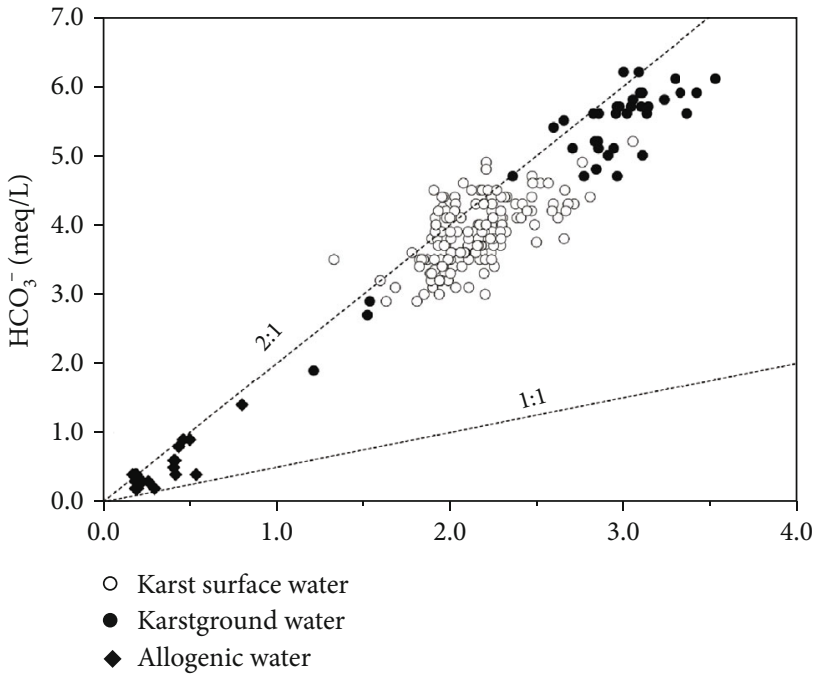

Figure 7: $\left(\mathrm{Ca}^{2+}+\mathrm{Mg}^{2+}\right) / \mathrm{HCO}_{3}{ }^{-}$of the surface and underground waters in Shanmuhe Catchment.

and then, $\mathrm{Mg}^{2+} / \mathrm{Ca}^{2+}$ approaches 1 [24]. $\mathrm{Mg}^{2+} / \mathrm{Ca}^{2+}$ in the karst surface water and groundwater is higher than 0.50 . Most of the groundwater has $\mathrm{Mg}^{2+} / \mathrm{Ca}^{2+}>0.75$, which is close to 1 .

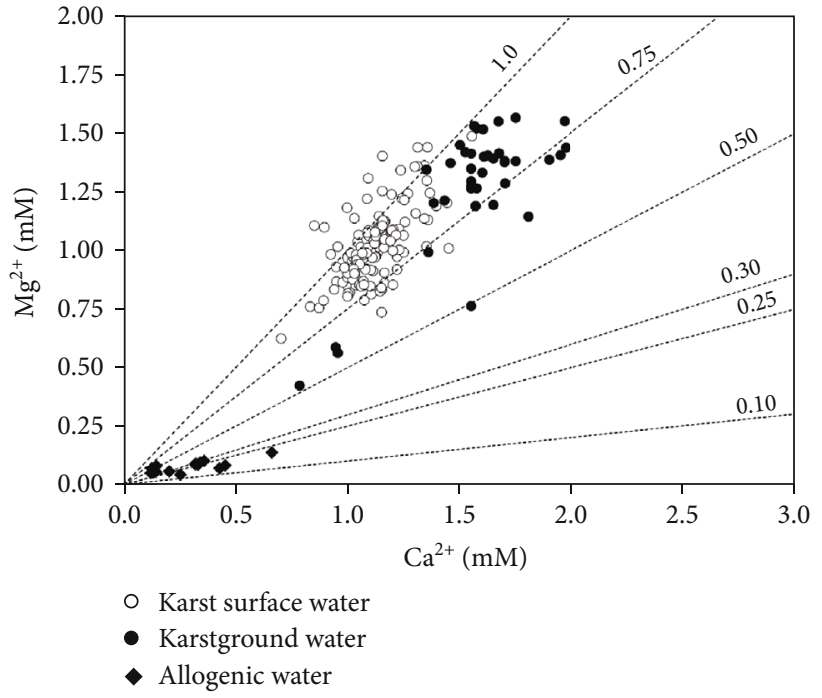

FIgURE 8: Molar concentration between $\mathrm{Mg}^{2+}$ and $\mathrm{Ca}^{2+}$ of the surface and underground waters in Shanmuhe Catchment.

A small part is between 0.50 and 0.75 , with an average value of $0.81 \pm 0.12$. The trend of $\mathrm{Mg}^{2+} / \mathrm{Ca}^{2+}$ in karst surface water samples is similar to that of the groundwater. Most of them 


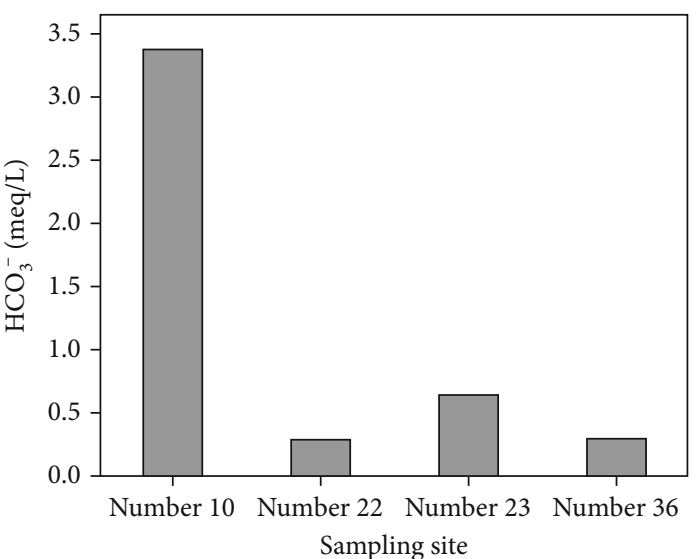

(a)

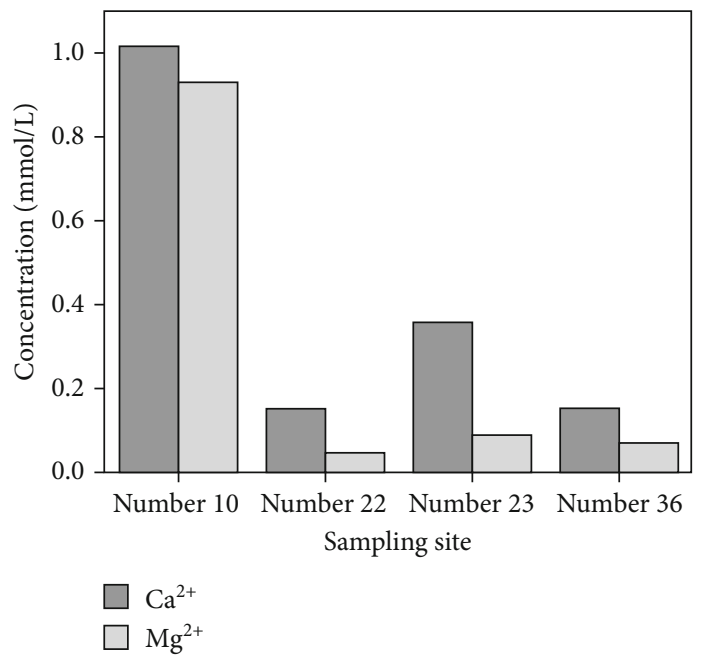

(c)

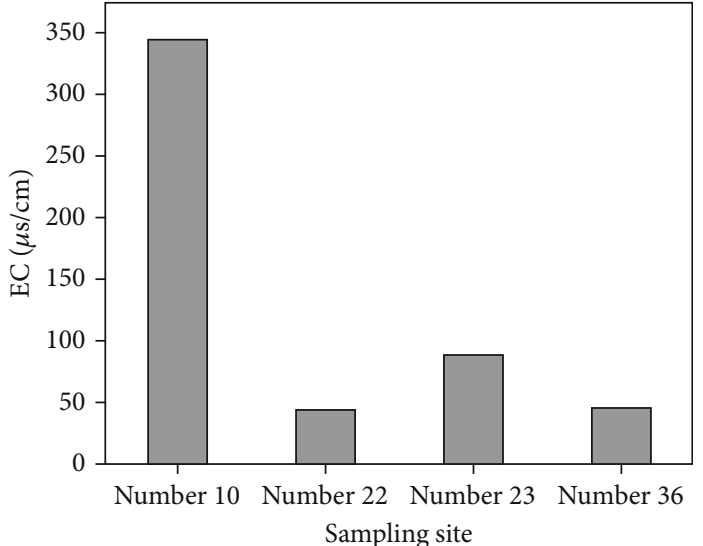

(b)

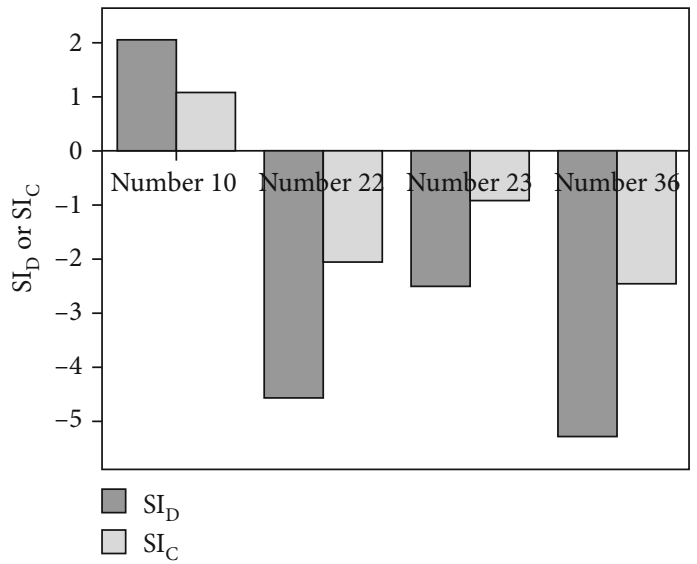

(d)

Figure 9: Water chemistry of No. 10 water and No. 22, 23, and 24 waters.

are located on the line of $\mathrm{Mg}^{2+} / \mathrm{Ca}^{2+}=0.75$, and their variation ranges from 0.64 to 1.30 , with an average value of 0.92 \pm 0.10 . The results show that $\mathrm{Ca}^{2+}, \mathrm{Mg}^{2+}$, and $\mathrm{HCO}_{3}{ }^{-}$in karst surface water and groundwater mainly come from dolomite mineral dissolution, and the contribution of limestone mineral dissolution is small. The $\mathrm{Ca} / \mathrm{Mg}$ ratios are almost all around 1 in the samples of Shilengshui Formation and Loushanguan Formation in the basin, which fully indicates the control of dolomite on hydrochemistry. $\mathrm{Mg}^{2+} / \mathrm{Ca}^{2+}$ in karst surface water is higher than that in groundwater. The possible reason is that after the groundwater is exposed to become surface water, $\mathrm{CO}_{2}$ in the water degasses, resulting in $\mathrm{CaCO}_{3}$ deposition, which makes the concentration of $\mathrm{Ca}^{2+}$ in the water decrease relatively.

(2) The Geochemical Effect of Other Lithology on Main Ions. Lithology determines the hydrochemical composition of the basin and is the material basis for the formation of hydrochemistry. Figure 2 shows that the surface water and groundwater in the basin are $\mathrm{HCO}_{3}-\mathrm{Ca} \cdot \mathrm{Mg}$, and the allogenic water is $\mathrm{HCO}_{3}$-Ca type. The karst water is mainly controlled by dolomite mineral dissolution, while the allogenic water is mainly controlled by shale. Comparing the hydrochemistry of the allogenic surface water (Tangtou River 22, Chayuan River 23) and outcropped spring water (Hetaoping 36) flowing through the northern shale area of the basin with that of surface water (Liangcha River East No. 10) flowing into the dolomite karst area (Figure 9), the main ion composition and saturation index are obviously different. $\mathrm{Ca}^{2+}$ is the main cation in the water flowing through the shale area, and $\mathrm{Mg}^{2+}$ content is very low. Therefore, the $\mathrm{Mg}^{2+} / \mathrm{Ca}^{2+}$ ratio in the allogenic water is the lowest (Figure 8), which is mainly related to the fact that the $\mathrm{Mg}$ content in rock is lower than that of Ca. Tests of noncarbonate rock samples from the Cambrian Bianmachong Formation in Hetaoping show that $\mathrm{CaO}$ and $\mathrm{MgO}$ account for $4.63 \%$ and $1.01 \%$, respectively, while dolomite and calcite account for $4.62 \%$ and $5.75 \%$, respectively. The content of $\mathrm{HCO}_{3}{ }^{-}$in anions is very low with an average of $0.49 \mathrm{mmol} / \mathrm{L}$, and the concentration and proportion of $\mathrm{Ca}^{2+}, \mathrm{Mg}^{2+}$, and $\mathrm{HCO}_{3}{ }^{-}$in anions are obviously increased after they flow through dolomite area. Significant differences in major ions also lead to significant differences in conductivity. In terms of $\mathrm{SI}_{C}$ and $\mathrm{SI}_{\mathrm{D}}$, both $\mathrm{SI}_{\mathrm{C}}$ and $\mathrm{SI}_{\mathrm{D}}$ in water flowing through shale area are negative and have 
strong dissolution ability, while after flowing through dolomite area, $\mathrm{SI}_{\mathrm{C}}$ and $\mathrm{SI}_{\mathrm{D}}$ reach 1.04 and 2.05, respectively, reaching supersaturation state.

4.4. Influence of Atmospheric Precipitation. Surface water and groundwater in Shibing Shanmuhe Basin mainly come from atmospheric precipitation, but due to the relatively low ion composition in precipitation, its main influence is dilution. However, the low $\mathrm{pH}$ of atmospheric precipitation in the study area can lead to the decrease of the $\mathrm{pH}$ of karst water, thus enhancing the carbonate karst dissolution and increasing the conductivity of the basin. According to the Gibbs diagram above, the hydrochemistry of the basin belongs to rock weathering type. Therefore, the contribution of atmospheric precipitation to the chemical ion composition of basin water is very restricted.

4.5. Influence of Human Activities. The concentrations of $\mathrm{K}^{+}$, $\mathrm{Na}^{+}, \mathrm{NO}_{3}{ }^{-}, \mathrm{Cl}^{-}$, and $\mathrm{SO}_{4}{ }^{2-}$ in the water in the study area are very low. Because the study area is a world natural heritage site, there are no serious human pollutions such as industrial activities, but rather only a small area of traditional agricultural activities whose impact is very small. The typical dolomite karst ecosystem has been well preserved in the study area, and a large area of primary forest vegetation and diversified ecosystem has been preserved and developed. Primitive central subtropical evergreen broad-leaved forest ecosystem has been formed in the middle and lower parts of the mountain. Mountainous evergreen hard-leaved forest and coniferous forest have been formed at the top of the ridge and mountain. They belong to the top community type of recessive karst forest vegetation, including woodland coniferous forest shrubs and sparse woodlands that account for more than $87 \%$ of the total area of the study area. Therefore, human activities have little effect on the hydrochemistry of the basin.

\section{Discussions}

(1) The $\mathrm{pH}$ of surface water and groundwater in typical dolomite basin in humid subtropical zone is neutral to alkaline, controlled mainly by geological background, and the hydrochemistry of surface water and groundwater is quite different. However, $\mathrm{Ca}^{2+}$, $\mathrm{Mg}^{2+}$, and $\mathrm{HCO}_{3}{ }^{-}$are the main ions in surface water and groundwater in the dolomite karst basin. The hydrochemical type in typical dolomite basin in humid subtropical zone is $\mathrm{HCO}_{3}-\mathrm{Ca} \cdot \mathrm{Mg}$ type, which is the same as the previous study by Zhang [20]. It is different from the hydrochemical types in limestone and shale districts, in which the proportion of $\mathrm{Cl}^{-}$, $\mathrm{NO}_{3}{ }^{-}$, and $\mathrm{SO}_{4}{ }^{2-}$ is higher, and the hydrochemical type is $\mathrm{HCO}_{3}-\mathrm{Ca}$. The hydrochemical type in limestone area is also $\mathrm{HCO}_{3}$-Ca type

(2) Controlled by lithology, EC, $\mathrm{Ca}^{2+}, \mathrm{Mg}^{2+}, \mathrm{HCO}_{3}^{-}$, $\mathrm{Mg}^{2+} / \mathrm{Ca}^{2+}$, and $\mathrm{Mg}^{2+} / \mathrm{HCO}_{3}^{-}$have similar spatial variations, which are lower in allogenic water in the upstream and northwest of the basin and become higher when the water enters the dolomite karst area in the mid and downstream of the basin. $\mathrm{HCO}_{3}{ }^{-}$concentration and $\mathrm{Mg}^{2+} / \mathrm{Ca}^{2+}$ in the pure dolomite basin are higher than those in the impure dolomite basin. Although the dissolution rate of dolomite is slower than that of limestone, its higher solubility results in more $\mathrm{HCO}_{3}{ }^{-} \cdot \mathrm{SI}_{\mathrm{C}}$ and $\mathrm{SI}_{\mathrm{D}}$ of the allogenic water are below zero, which strongly erodes the carbonate rocks in the basin. As a result, $\mathrm{Ca}^{2+}, \mathrm{Mg}^{2+}$, and $\mathrm{HCO}_{3}{ }^{-}$of the allogenic water entering the karst area are significantly increased

(3) The monthly variation of hydrochemistry shows that the seasonal variation of ion concentration is not obvious, and there is a dilution effect in rainy season, but the variation of ion concentration is small and relatively stable, indicating that water-rock interaction may be the main factor affecting ion concentration

(4) TDS and $\mathrm{Na}^{+} /\left(\mathrm{Na}^{+}+\mathrm{Ca}^{2+}\right), \mathrm{Cl}^{-} /\left(\mathrm{Cl}^{-}+\mathrm{HCO}_{3}{ }^{-}\right)$indicate that surface water and groundwater in the basin are mainly controlled by rock weathering, and rainfall has little effect. $\left(\mathrm{Ca}^{2+}+\mathrm{Mg}^{2+}\right) / \mathrm{HCO}_{3}{ }^{-}$samples locate near the 2:1 line of mineral dissolution reaction of carbonate rocks, which indicates that the formation and variation of hydrochemistry in surface water and groundwater in karst basin are mainly controlled by carbonate weathering. Atmospheric precipitation and allogenic water have some influence on the input of $\mathrm{Ca}^{2+}$ and $\mathrm{Mg}^{2+}$ in karst water, which makes the ion balance slightly biased towards cations. Low concentrations of $\mathrm{K}^{+}, \mathrm{Na}^{+}, \mathrm{NO}_{3}^{-}, \mathrm{Cl}^{-}$, and $\mathrm{SO}_{4}{ }^{2-}$ in water indicate that human activities have little effect on the hydrochemistry in the study area

\section{Conclusions}

The hydrochemical characteristics and variation rules of water in the humid subtropical karst areas in the Shanmuhe Basin and its subbasin Huangzhouhe Basin in Shibing Dolomite Karst World Natural Heritage Site in China were studied. 215 water samples were collected and analyzed; the geochemical data were elaborated by using graphical methods and calculation of saturation indexes. It was found that the hydrochemical type in typical dolomite basin in humid subtropical zone is $\mathrm{HCO}_{3}{ }^{-} \mathrm{Ca} \cdot \mathrm{Mg}$ type, and the water-rock interaction may be the main factor affecting the hydrochemical characteristics through carbonate weathering. The lithology is the main influencing factors of the hydrochemical features of the study area which is less affected by human activities.

\section{Data Availability}

The data used to support the findings of this study are available from the corresponding author upon request.

\section{Conflicts of Interest}

The authors declare that they have no conflicts of interest. 


\section{Authors' Contributions}

SX was in charge of designing the study topic and writing the manuscript. JW, CZ, and JL were in charge of checking the research results and paper structures. YD and JH performed the experiments, and HX was in charge of mapping.

\section{Acknowledgments}

This work was financially supported by the Project of National Key Research and Development Program of China in the 13th Five-Year Plan (2016YFC0502606-01), the National Natural Science Foundation of China (41673129), the Sci \& Tech Project of Guizhou Province, China (Qian-ke-he LH [2015]7775), the Science and Technology Cooperation Project of Guizhou Province (No. LH [2017]7059), and the doctoral research project supported by Guizhou Normal University (GZNUD [2017]12).

\section{References}

[1] G. L. Han and C. Q. Liu, "Research on rivers in the karst area of Guizhou: Hydrogeochemical characteristics of carbonate rock dissolution control," Advances in Geography, vol. 20, pp. 394406, 2005.

[2] T. T. Li, H. B. Ji, Y. B. Jiang, and L. X. Wang, "Influencing factors and DIC sources of water chemistry in the upper Gan River," Journal of Geography, vol. 62, pp. 764-775, 2007.

[3] X. W. Tang, J. K. Wu, L. Y. Xue et al., "Main ion characteristics and control factors of surface water chemistry in the Xilin River Basin," Environmental Science, vol. 35, pp. 131-142, 2014.

[4] L. C. Zhang, W. J. Dong, and L. P. Wang, "Geochemical characteristics of the Yangtze River waters," Acta Geographica Sinica, vol. 47, pp. 220-232, 1992.

[5] J. X. Zhou, Y. J. Ding, G. X. Zeng, J. K. Wu, and J. Qin, "Main ion characteristics and control factors of surface water hydrochemistry in the upper reaches of Shule River," Environmental Science, vol. 35, pp. 3315-3324, 2014.

[6] D. C. Ford, "Characteristics of limestone solution in the southern Rocky Mountains and Selkirk Mountains, Alberta and British Columbia," Canadian Journal of Earth Sciences, vol. 8, no. 6, pp. 585-609, 1971.

[7] T. M. L. Wigley, "The incongruent solution of dolomite," Geochimica et Cosmochimica Acta, vol. 37, no. 5, pp. 1397-1402, 1973.

[8] M. K. Woo and P. Marsh, "Effect of vegetation on limestone solution in a small High Arctic basin," Canadian Journal of Earth Sciences, vol. 14, no. 4, pp. 571-581, 1977.

[9] T. Pu, Y. Q. He, G. F. Zhu et al., "Surface-groundwater hydrochemical characteristics and control factors in the Lijiang Basin," Environmental Science, vol. 33, pp. 48-55, 2012.

[10] Y. C. Lang, C. Q. Liu, Z. Q. Zhao, S. L. Li, and G. L. Han, "Surface-groundwater chemical composition of Guiyang City, karst hydrological system water-rock reaction and pollution characteristics," Advances in Water Science, vol. 16, pp. 826832, 2005.

[11] J. B. Pu, Z. C. Jiang, D. X. Yuan, and C. Zhang, "Progress in research on rock weathering carbon sinks: based on the analysis of the IPCC's fifth climate change assessment report," Advances in Earth Science, vol. 30, pp. 1081-1090, 2015.
[12] F. Guo, G. H. Jiang, X. Qing, and K. Li, "Characteristics of hydrochemical changes of karst groundwater under the influence of land use," China Karst, vol. 26, pp. 212-218, 2007.

[13] Y. N. Jia and D. X. Yuan, "The effect of land use on karst water quality in Shuicheng Basin, Guizhou," Acta Geographica Sinica, vol. 58, pp. 632-838, 2003.

[14] Y. J. Jiang, D. X. Yuan, S. Y. Xie, L. L. Li, G. Zhang, and R. S. $\mathrm{He}$, "Analysis of groundwater quality and land use change in a typical karst agricultural area-taking the Xiaojiang River Basin in Yunnan as an example," Acta Geographica Sinica, vol. 61, pp. 471-481, 2006.

[15] S. Z. Xiao, J. C. Lan, D. X. Yuan, W. Y. L. Yang, and X. H. Ao, "Hydrochemistry and dissolved inorganic carbon stable isotope of Shibing dolomite karst area in Guizhou Province," Environmental Science, vol. 36, pp. 2085-2093, 2015.

[16] M. Zhao, C. Zeng, and Z. H. Liu, "Effect of land use change on dissolved inorganic carbon and its stable isotope composition in karst groundwater," Geochemistry, vol. 38, pp. 565-572, 2009.

[17] X. W. Zhang, X. P. Zhou, and S. Q. Xu, "Effects of agricultural activities on dissolved inorganic carbon and stable carbon isotopes in surface karst springs," Journal of Soil and Water Conservation, vol. 27, pp. 218-227, 2013.

[18] C. Zhang, Z. C. Jiang, M. Worakul, J. B. Pu, and Y. Lv, "Karst landforms and hydrogeochemical characteristics in western Thailand and their comparison with karst in southwest China," China Karst, vol. 33, pp. 1-8, 2014.

[19] D. W. Cowell and D. C. Ford, "Hydrochemistry of a dolomite karst: the Bruce Peninsula of Ontario," Canadian Journal of Earth Sciences, vol. 17, no. 4, pp. 520-526, 1980.

[20] Z. G. Zhang, Karstogenesis-Theoretical Exploration, Guangxi Normal University Press, Guilin, 2006.

[21] D. C. Ford and P. Williams, Karst Hydrogeology and Geomorphology, John Wiley \& Sons Inc., 2007.

[22] Liberation Army No 732, Survey report of hydrogeology of Zhenyuan in 1/200000, Tech. Rep, 1977.

[23] J. H. Feth and R. J. Gibbs, "Mechanisms controlling world water chemistry: evaporation-crystallization process," Science, vol. 172, no. 3985, pp. 870-872, 1970.

[24] K. Szramek, J. C. McIntosh, E. L. Williams, T. Kanduc, N. Ogrinc, and L. M. Walter, "Relative weathering intensity of calcite versus dolomite in carbonate-bearing temperate zone watersheds: carbonate geochemistry and fluxes from catchments within the St. Lawrence and Danube river basins," Geochemistry, Geophysics, Geosystems, vol. 8, no. 4, pp. 2-26, 2007. 